\title{
BAHAN AJAR BERORIENTASI ENVIRONMENTAL SUSTAINABILITY EDUCATION BERINTEGRASI KEARIFAN LOKAL UNTUK MENINGKATKAN LITERASI SAINS MAHASISWA
}

\author{
Magfirah Perkasa \\ STKIP BIMA \\ Jl. Piere Tendean, Mpunda, Nusa Tenggara Barat, Bima \\ Email: magfirahperkasa@gmail.com
}

\begin{abstract}
Abstrak:
Penelitian ini bertujuan untuk mengembangkan bahan ajar berorientasi environmental sustainability education berintegrasi kearifan lokal Mbojo untuk meningkatkan literasi sains mahasiswa kimia. Penelitian ini merupakan penelitian pengembangan dengan menggunakan model pengembangan diadaptasi dari model Dick \& Carey menjadi empat tahapan dengan subjek coba produk pada mahasiswa semester 2 STKIP Bima. Instrumen pengumpulan data yang digunakan yaitu lembar validasi, tes literasi kimia berformat benar-salah beralasan dan lembar penilaian diri. Hasil penelitian menunjukkan bahwa: (1) bahan ajar berorientasi environmental sustainability education berintegrasi kearifan lokal Mbojo yang dikembangkan memiliki karakteristik yang meliputi pengembangan melalui model project based learning pada materi Kimia Karbon dan Peranannya terhadap Lingkungan; dan indikator literasi sains diadaptasi dari aspek competencies dan attitudes pada indikator literasi sains OECD; (2) bahan ajar berorientasi environmental sustainability education berintegrasi kearifan lokal Mbojo yang dikembangkan layak digunakan dengan kategori sangat baik serta efektif untuk meningkatkan literasi sains mahasiswa berdasarkan uji MannWhitney U.
\end{abstract}

\begin{abstract}
:
The research aims to reveal the developing teaching material based on environmental sustainability education integrated with Mbojo local wisdom to enhance students' scientific literacy. The developing model adapted from Dick \& Carey and the trial of this research product was conducted to 2nd semester students at chemistry education department of STKIP Bima. The instruments for data collection are validation instrument, a true-false reasoning scientific literacy test and self-assessment. The results of research shows: (1) the features of product research is using project based learning to Hydrocarbon and The Role for Environment topic; and the indicators for scientific literacy test adapted from competencies and attitudes aspects in OECD scientific literacy indicator; (2) chemistry learning tools based on environmental sustainability education integrated with Mbojo local wisdom is valid to use with very good category and effective to enhance scientific literacy based on Mann-Whitney U test results.
\end{abstract}

Kata kunci:

Bahan Ajar, Pendidikan Lingkungan, Environmental Sustainability Education, Kearifan Lokal Mbojo, Literasi Sains.

ARUS globalisasi dan berbagai isu yang terkait dengan masalah lingkungan serta perkembangan ilmu pengetahuan, teknologi dan seni (IPTEKS) menuntut sumber 
daya manusia (SDM) yang melek sains, melek teknologi dan pengetahuan baru. Melek sains dan teknologi dalam pembelajaran sains merupakan suatu capaian belajar yang lebih tinggi. Hal ini menjadi tantangan yang harus dihadapi oleh pemerintah, akademisi dan stakeholder pendidikan. Melalui pemanfaatan sumber belajar dari lingkungan sekitar dan kehidupan sehari-hari, pembelajaran dapat mengembangkan kreativitas dalam sains, keterampilan proses sains, kemampuan berpikir, bersikap ilmiah, dan mampu menyelesaikan masalah-masalah secara ilmiah (scientific literacy) pada lingkungan sekitar (lokal). Seseorang dinyatakan memiliki literasi sains apabila memiliki kemampuan mengidentifikasi, menganalisis, dan mengolah konsep kimia (sains) untuk menyelesaikan masalahnya dalam kehidupan sehari-hari dan mampu menjelaskan tiap fenomena kimia yang terjadi disekitarnya secara ilmiah. Bybee juga mendeskripsikan bahwa literasi sains untuk seorang pembelajar dengan usia diatas 15 tahun terdiri dari lima level (Shwartz, Ben-Zvi, \& Hofstein, 2006; Soobard \& Rannikmae, 2011). Lima level literasi sains disajikan lebih jelas pada tabel 1 .

Tabel 1. Pengklasifikasian Level Literasi Sains

\begin{tabular}{|c|c|c|}
\hline Level & Literasi & Kemampuan \\
\hline 1 & Scientific illiteracy & $\begin{array}{l}\text { Tidak mampu menjelaskan, menghubungkan } \\
\text { fenomena sekitar secara ilmiah }\end{array}$ \\
\hline 2 & $\begin{array}{l}\text { Nominal Scientific } \\
\text { Literacy }\end{array}$ & $\begin{array}{l}\text { Mengenal konsep sains tetapi masih } \\
\text { memungkinkan terjadinya miskonsepsi }\end{array}$ \\
\hline 3 & $\begin{array}{l}\text { Functional Scientific } \\
\text { Literacy }\end{array}$ & $\begin{array}{l}\text { Menjelaskan dan mendefinisikan konsep sains } \\
\text { dengan benar dan secara ilmiah, tetapi memiliki } \\
\text { keterbatasan pengetahuan tentang konsep terkait }\end{array}$ \\
\hline 4 & $\begin{array}{l}\text { Conceptual Scientific } \\
\text { Literacy }\end{array}$ & $\begin{array}{l}\text { Mengembangkan pemahaman tentang konsep } \\
\text { sains terkait dan menghubungkannya dengan } \\
\text { konsep lain untuk membentuk pemahaman yang } \\
\text { utuh }\end{array}$ \\
\hline 5 & $\begin{array}{l}\text { Multidimensional } \\
\text { Scientific Literacy }\end{array}$ & $\begin{array}{l}\text { Mengembangkan pemahaman tentang konsep } \\
\text { sains terkait baik secara ilmiah maupun filosofis } \\
\text { dan menerapkannya dalam kehidupan sehari-hari }\end{array}$ \\
\hline
\end{tabular}

Hasil Program for International Student Assessment (PISA) dua tahun berturut 2012 dan 2015 menunjukkan bahwa literasi sains yang dimiliki siswa di Indonesia masih dibawah rata-rata (OECD, 2014: 5). PISA merupakan sebuah survei internasional tiga tahunan yang bertujuan untuk mengevaluasi sistem pendidikan di seluruh dunia dengan menguji keterampilan dan pengetahuan siswa. Mengingat akan rendahnya literasi sains yang dimiliki siswa Indonesia, maka literasi sains perlu disisipkan dalam kurikulum pendidikan serta dalam proses pembelajaran sains di Indonesia, baik kurikulum pendidikan dasar dan menengah maupun pendidikan tinggi. Berdasarkan wawancara singkat dengan beberapa akademisi dan tenaga 
pendidik di daerah Kota Bima, istilah literasi sains masih dianggap asing dan hampir tidak pernah dinilai dengan baik serta pembelajaran kimia khususnya di tataran pendidikan tinggi masih berorientasi pada penilaian aspek pengetahuan.

Literasi sains dapat dibekalkan kepada mahasiswa dengan merangsang mahasiswa memanfaatkan sumber belajar di lingkungan sekitar salah satunya dengan memanfaatkan potensi dan kearifan lokal. Permasalahan lingkungan yang terjadi di sekitar serta berbagai isu budaya lokal yang berkembang dapat dijadikan sarana untuk membelajarkan seorang pembelajar tentang literasi sains. Suku Mbojo sebagai salah satu etnis yang mendiami pulau Sumbawa bagian timur juga memiliki petuah dan nasehat budaya yang berkaitan dengan kelestarian lingkungan hidup dan penghormatan kepada lingkungan seperti: ngaha aina ngoho (ambillah secukupnya dan jangan merusak hutan) dan maja labo dahu (malu dan takut, yakni malu pada hukum Allah, malu pada manusia, malu pada lingkungan) (Masita, 2012).

Terdapat beberapa kata-kata pesan atau petuah yang berkaitan dengan kelestarian lingkungan hidup dan penghormatan kepada orangtua dan lingkungan seperti: ngaha aina ngoho (ambillah secukupnya dan jangan merusak hutan) hormat ndei dou ma tua lao guru (hormat kepada orang tua dan guru), aina sombo anae (jangan sombong anakku), marumpa si doumatua waapu salam (kalau ketemu orang yang lebih tua dan orang tua sampaikan salam), ma mpaa lao rewomu aina pili-pili lengamu anae (kalau di dalam pergaulan jangan pilih-pilih temanmu anakku), dan maja labo dahu (malu dan takut, yakni malu pada hukum Allah, malu pada manusia, malu pada lingkungan) (Masita, 2012).

Masalah terkait rendahnya literasi sains dapat diminimalisir dengan pembelajaran kimia berbasis pendidikan lingkungan berkelanjutan (environmental sustainability education). Pembelajaran berbasis pendidikan lingkungan telah dilakukan di beberapa negara dan menjadi landasan penerapan beberapa strategi belajar yang berkaitan dengan sustainability oleh United Nations Educational, Scientific, and Cultural Organization (UNESCO) dan Organization for Economic Co-operation and Development (OECD) untuk meningkatkan literasi sains dan kesadaran terhadap lingkungan (OECD, 2013: 4; UNESCO, 2002: 37). Konsep berkelanjutan ini dapat dibelajarkan dalam proses pembelajaran dengan beberapa strategi pembelajaran, diantaranya experiential learning (Perkasa \& Aznam, 2016; Redman, 2013), project based learning (Jollands \& Parthasarathy, 2013; Micangeli, Naso, \& Matrisciano, 2014), storytelling, values education, inquiry learning, appropriate assessment, future problem-solving, learning outside the classroom, $\mathcal{E}$ community problem solving (UNESCO, 2002: 5). Model project based learning yang digunakan pada penelitian ini merupakan salah satu model yang direkomendasikan oleh UNESCO untuk implementasi konsep pendidikan berkelanjutan (UNESCO, 2002: 4). Model project based learning memiliki beberapa tahapan sintaks meliputi: (1) Menentukan pertanyaan mendasar; (2) Menyusun rencana proyek; (3) Menyusun jadwal; (4) Memantau kemajuan proyek (monitoring); (5) Menilai hasil; dan (6) Evaluasi pengalaman. Oleh karena itu, untuk menyelesaikan beberapa masalah di atas, perlu adanya pengembangan bahan ajar berorientasi 
environmental sustainability education berintegrasi kearifan lokal Mbojo pada pendidikan tinggi yang bertujuan untuk membekali dan meningkatkan literasi sains mahasiswa.

\section{METODE PENELITIAN}

Penelitian ini merupakan penelitian pengembangan atau Research and Development $(R \in \mathcal{E} D$ ). Model pengembangan yang digunakan yaitu adaptasi dari model Dick \& Carey (Dick, Carey, \& Carey, 2001: 13) dengan sepuluh langkah sebagaimana ditunjukkan pada gambar 1, dalam penelitian ini dimodifikasi menjadi empat langkah yaitu pendahuluan, analisis, pengembangan, dan pengujian.

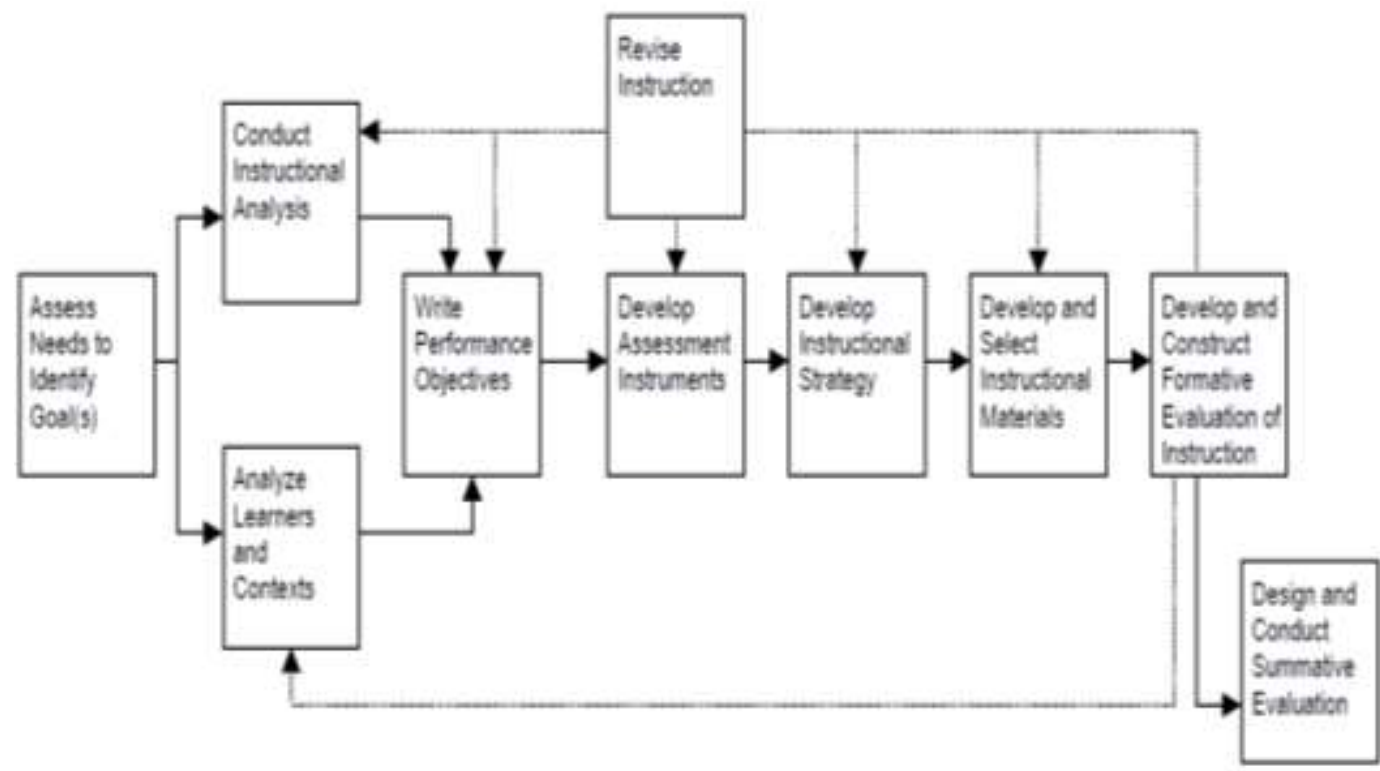

Gambar 1. Model Pengembangan Dick \& Carey

Penelitian dilaksanakan pada semester genap tahun akademik 2017/2018. Penelitian ini dilakukan di Program Studi Pendidikan Kimia STKIP Bima dengan subjek uji coba yaitu mahasiswa kelas A semester II (desain one to one).

Pada tahap pendahuluan dilakukan dua kegiatan yaitu studi pendahuluan dan studi literatur. Studi pendahuluan ditujukan untuk mengetahui kebutuhan pengguna produk dan dilakukan dengan cara observasi perkuliahan dan wawancara mahasiswa serta beberapa dosen di lingkungan STKIP Bima. Studi literatur ditujukan untuk mengumpulkan data teoretis terkait variabel yang akan dijadikan fokus pengembangan dalam penelitian ini. Tahap analisis dilakukan untuk menganalisis komponen-komponen utama yang terdapat dalam seperangkat bahan ajar yaitu dengan menganalisis mahasiswa, menganalisis silabus dan rencana perkuliahan semester (RPS), menganalisis struktur isi dan konsep, dan menganalisis tujuan perkuliahan. Tahap pengembangan dilakukan dengan mengembangkan produk berupa bahan ajar berorientasi environmental sustainability education berintegrasi kearifan lokal Mbojo untuk meningkatkan literasi sains mahasiswa. Tahap akhir yaitu 
pengujian dengan mengujikan produk. Tahap pengujian dilakukan bertujuan untuk ketercapaian tujuan pengembangan dan tingkat kelayakan produk bahan ajar.

Data kelayakan produk diperoleh dengan validasi logis yang dilakukan oleh dosen ahli menggunakan lembar validasi yang dianalisis secara kualitatif. Tes yang diberikan kepada mahasiswa berupa tes literasi sains yang berformat benar-salah beralasan sebanyak 15 item yang disusun dengan indikator yang diadaptasi dari draft science framework PISA 2015 untuk aspek competencies dengan sub-aspek explain phenomena scientifically dan interpret evidence and data scientifically. Teknik dan instrumen pengumpulan data disajikan pada tabel 2.

Tabel 2. Teknik dan Instrumen Pengumpulan Data

\begin{tabular}{ll}
\hline \multicolumn{1}{c}{ Jenis } & \multicolumn{1}{c}{ Instrumen } \\
\hline Wawancara & Daftar Pertanyaan \\
Observasi & Lembar Observasi Keterlaksanaan RPP \\
Literasi Sains & Tes Literasi Kimia \\
Sikap (Data Pendukung) & Lembar Penilaian Diri \\
\hline
\end{tabular}

Hasil perhitungan skor validasi untuk masing-masing komponen produk digunakan untuk mengkategorikan kelayakan produk pengembangan yang disajikan pada tabel 3.

Tabel 3. Kategori Kelayakan Produk Pengembangan

\begin{tabular}{|c|c|c|c|c|}
\hline \multicolumn{3}{|c|}{ Interval Komponen Produk } & \multirow[b]{2}{*}{ Nilai } & \multirow[b]{2}{*}{ Kategori } \\
\hline RPS & Diktat Kuliah & $\begin{array}{c}\text { Instrumen } \\
\text { Penilaian }\end{array}$ & & \\
\hline$x \geq 65,1$ & $x \geq 34,1$ & $x \geq 12,4$ & $\mathrm{~A}$ & Sangat Baik \\
\hline $65,1>x \geq 52,5$ & $34,1>x \geq 27,5$ & $12,4>x \geq 10$ & B & Baik \\
\hline $52,5>x \geq 39,9$ & $27,5>x \geq 20,9$ & $10>x \geq 7,6$ & $\mathrm{C}$ & Tidak Baik \\
\hline$x<39,9$ & $x<20,9$ & $x<7,6$ & $\mathrm{D}$ & $\begin{array}{c}\text { Sangat Tidak } \\
\text { Baik }\end{array}$ \\
\hline
\end{tabular}

Keterlaksanaan pembelajaran ditinjau dari tercapainya seluruh langkah pembelajaran yang telah disusun dalam RPS. Kategori keterlaksanaan pembelajaran dikategorikan menjadi tinggi dengan kategori kertercapaian $\geq 80 \%$, sedang dengan kategori kertercapaian $65 \%-80 \%$ dan rendah dengan kategori kertercapaian $<65 \%$.

Peningkatan literasi sains mahasiswa dianalisis dengan menghitung skor perolehan (gain score). Gain skor dikategorikan menjadi tinggi, sedang dan rendah yang disajikan berdasarkan kriteria pada tabel 4 .

Tabel 4. Kategori Gain Skor

\begin{tabular}{ccc}
\hline No. & Kriteria Gain Skor & Kategori \\
\hline 1. & $\langle g\rangle \geq 0,7$ & Tinggi \\
2. & $0,7>\langle g\rangle \geq 0,3$ & Sedang \\
3. & $\langle g\rangle<0,3$ & Rendah \\
\hline
\end{tabular}

(Hake, 1998) 
Keefektifan bahan ajar berorientasi environmental sustainability education yang terintegrasi kearifan lokal dengan tujuan untuk meningkatkan literasi sains mahasiswa dianalisis secara statistik menggunakan uji Mann-Whitney U dengan bantuan program SPSS 16.

\section{HASIL PENELITIAN DAN PEMBAHASAN}

\section{Hasil Pengembangan}

Draft produk bahan ajar berorientasi environmental sustainability education yang terintegrasi kearifan lokal yang telah dikembangkan memiliki karakteristik yang diuraikan berikut: produk bahan ajar yang dikembangkan meliputi RPS, diktat kuliah dan instrumen penilaian literasi mahasiswa; Konsep environmental sustainability education yang terintegrasi kearifan lokal diimplementasikan melalui model pembelajaran project based learning melalui proyek dan uraian kegiatan yang berhubungan dengan lingkungan dan masyarakat sekitar kampus STKIP Bima; RPS memuat rencana pembelajaran selama satu semester dengan tampilan RPS termuat digambar 2, namun pada diktat perkuliahan terbatas hanya memuat materi dan uraian kegiatan mahasiswa pada materi kimia karbon dan peranannya terhadap lingkungan; instrumen penilaian literasi sains mahasiswa dikembangkan berformat benar salah beralasan dengan indikator literasi sains diadaptasi dari aspek competencies pada draft science framework PISA, tampilannya disajikan pada gambar 2.

\begin{tabular}{|c|c|c|c|c|c|c|c|}
\hline \multicolumn{8}{|l|}{ MK Pranyarat } \\
\hline Minggu Ke & $\begin{array}{l}\text { Kemampuan Akhir yang } \\
\text { Diharapkan }\end{array}$ & Bahan Kajian & $\begin{array}{c}\text { Bentuk } \\
\text { Pembelajaran }\end{array}$ & Waktu & $\begin{array}{c}\text { Pengalaman } \\
\text { Belajar Mahasiswa }\end{array}$ & $\begin{array}{l}\text { Kriteria Penilaian } \\
\text { dan Indikator }\end{array}$ & Bobot Nitai \\
\hline $9-11$ & $\begin{array}{l}\text { Mampu menjabarkan pengertian } \\
\text { reaksi reduksi oksidasi, } \\
\text { menentukan bilangan oksidasi } \\
\text { unsur, senyawa, menganalisis } \\
\text { aplikasi reaksi reduksi oksidasi } \\
\text { dalam kehidupan sehari-hari }\end{array}$ & $\begin{array}{c}\text { Reaksi Reduksi } \\
\text { Oksidasi }\end{array}$ & $\begin{array}{l}\text { Ekspositori, } \\
\text { Diskusi, } \\
\text { Brainstorming, } \\
\text { Studi Kasus } \\
\text { melalui paper }\end{array}$ & $3 \times\left(2 \times 50^{\prime}\right)$ & $\begin{array}{l}\text { Pembelajaran } \\
\text { kelompok, } \\
\text { penalaran, berlatih } \\
\text { menulis paper }\end{array}$ & $\begin{array}{c}\text { Tepat waktu } \\
\text { mengumpulkan } \\
\text { paper, kerjasama, } \\
\text { kebenaran konsep, } \\
\text { kelogisan alternatif } \\
\text { solusi }\end{array}$ & $15 \%$ \\
\hline $12-15$ & $\begin{array}{l}\text { Mampu membedakan senyawa } \\
\text { alkanA, alkena dan alkuna, } \\
\text { memberi namarnawa } \\
\text { hidrokarbon, mengidentifikasi } \\
\text { reaksi hidrokarbon, mengetahui } \\
\text { reaksi polimerisasi senyawa } \\
\text { hidrokarbon serta aplikasinya } \\
\text { (kandungan plastik), menganalisis } \\
\text { aplikasi materi Kimia Karbon } \\
\text { dalam kehidupan sehari-hari, } \\
\text { mengevaluasi dampak aplikasi } \\
\text { dan peranan Kimia Karbon dalam } \\
\text { kehidupan sehari-hari. }\end{array}$ & $\begin{array}{c}\text { Kimia Karbon dan } \\
\text { Peranannya }\end{array}$ & $\begin{array}{l}\text { Ekspositori, } \\
\text { Brainstorming, } \\
\text { Studi kasus, } \\
\text { pembuatan proyek }\end{array}$ & $4 \times\left(2 \times 50^{\prime}\right)$ & $\begin{array}{l}\text { Pembelajaran } \\
\text { kelompok, } \\
\text { penalaran studi } \\
\text { kasus, berlatih } \\
\text { membuat proyek, } \\
\text { berlatih menulis } \\
\text { paper }\end{array}$ & $\begin{array}{c}\text { Progres proyek, } \\
\text { kerjasama } \\
\text { kelompok, } \\
\text { kebenaran konsep, } \\
\text { kelogisan alternatif } \\
\text { solusi, } \\
\text { kebermanfeatan } \\
\text { solusi }\end{array}$ & $20 \%$ \\
\hline 16 & Ujian Akhir Semester & (UAS) & Tes & $2 \times 50^{\prime}$ & $\begin{array}{c}\text { Berpikir } \\
\text { konseptual, } \\
\text { penalaran }\end{array}$ & $\begin{array}{c}\text { Kelngkapan dan } \\
\text { kebenatan jawaban }\end{array}$ & $15 \%$ \\
\hline
\end{tabular}

Gambar 2. Tampilan Rencana Pembelajaran Semester 

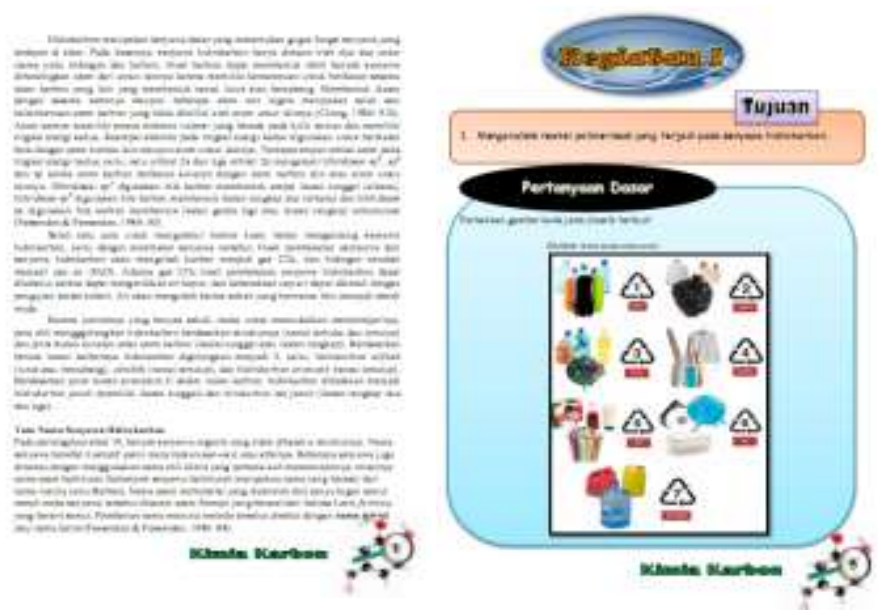

Gambar 3. Tampilan Diktat Kuliah

Kelayakan produk SSP kimia berbasis pendidikan berkelanjutan dianalisis dengan melakukan validasi logis. Validasi internal dilakukan untuk mengetahui kelayakan produk pengembangan untuk mencapai tujuan pengembangan berdasarkan penilaian secara kualitatif dari segi konstrak dan isi oleh dosen ahli. Hasil validasi internal oleh dosen ahli disajikan pada tabel 5.

Tabel 5. Skor Hasil Validasi Produk

\begin{tabular}{|c|c|c|c|c|}
\hline \multirow[b]{2}{*}{ No. } & \multirow[b]{2}{*}{ Validator } & \multicolumn{3}{|c|}{ Skor Penilaian Produk } \\
\hline & & RPS & $\begin{array}{c}\text { Diktat } \\
\text { perkuliahan }\end{array}$ & $\begin{array}{c}\text { Instrumen } \\
\text { Penilaian }\end{array}$ \\
\hline 1. & Dosen 1 & 84 & 42 & 16 \\
\hline 2. & Dosen 2 & 80 & 38 & 14 \\
\hline & Rata-rata & 82 & 40 & 15 \\
\hline & $\begin{array}{l}\text { Kategori } \\
\text { Celayakan }\end{array}$ & Sangat Baik & Sangat Baik & Sangat Baik \\
\hline
\end{tabular}

Berdasarkan kategori kelayakan produk yang disajikan, data skor validasi produk oleh dosen ahli menunjukkan bahwa produk bahan ajar yang terdiri dari RPS, dikat kuliah dan instrumen penilaian semuanya memiliki kelayakan "sangat baik". Kategori kelayakan sangat baik apabila rata-rata perolehan skor validasi dari dua validator lebih besar dari 65,1 untuk RPS, lebih besar dari 34,1 untuk diktat kuliah dan lebih besar dari 12,4 untuk instrumen penilaian. Kedua dosen ahli yang menjadi validator merupakan dosen yang memiliki kapasitas dan kepakaran dalam aspek pengembangan perangkat pembelajaran, bahan ajar dan menguasai konten materi.

\section{Hasil Pengujian}

Pengujian dilakukan pada mahasiswa kelas A semester II prodi Pendidikan Kimia STKIP Bima. Tahap pengujian dilakukan dengan desain pra-experimental design dengan bentuk one group pretest-postest. Mahasiswa semester II hanya terdaftar satu kelas. Pelaksanaan pembelajaran pada kelas uji dilakukan dengan menggunakan bahan ajar berorientasi environmental sustainability education yang terintegrasi kearifan 
lokal dikembangkan pada materi kimia karbon dan peranannya terhadap lingkungan. Pelaksanaan pembelajaran menggunakan bahan ajar berorientasi environmental sustainability education yang terintegrasi kearifan lokal bertujuan untuk meningkatkan literasi sains mahasiswa.

Tes literasi sains diberikan kepada mahasiswa sebelum (pretest) dan sesudah (posttest) mempelajari materi. Pretest dan posttest dilakukan dengan tujuan untuk mengetahui peningkatan literasi sains pada subjek uji coba. Keterlaksanaan pembelajaran dianalisis dengan menghitung persentase langkah pembelajaran yang dilakukan berdasarkan alokasi waktu pada tiap pertemuan. Pembelajaran yang memiliki nilai persentase keterlaksanaan $\geq 80 \%$ dapat dikategorikan tinggi dengan makna pelaksanaan langkah pembelajaran dapat dicapai dengan baik. Persentase keterlaksanaan pembelajaran disajikan pada tabel 6 .

Tabel 6. Keterlaksanaan Pembelajaran Kelas Uji

\begin{tabular}{ccccc}
\hline $\begin{array}{c}\text { Pertemuan } \\
\text { Ke- }\end{array}$ & $\begin{array}{c}\text { Jumlah } \\
\text { Kegiatan }\end{array}$ & $\begin{array}{c}\text { Skor } \\
\text { Observer }\end{array}$ & $\begin{array}{c}\text { Persentase } \\
\text { Keterlaksanaan } \\
\mathbf{( \% )}\end{array}$ & $\begin{array}{c}\text { Kategori } \\
\text { Keterlaksanaan }\end{array}$ \\
\hline 1 & 12 & 12 & 100,00 & Tinggi \\
2 & 12 & 12 & 100,00 & Tinggi \\
3 & 12 & 11 & 91,66 & Tinggi \\
\hline
\end{tabular}

Berdasarkan tabel 6 diperoleh informasi bahwa keterlaksanaan pembelajaran pada tahap pengujian lebih dari $80 \%$ yang bermakna bahwa pelaksanaan dan semua kegiatan pembelajaran terlaksana dan dilakukan dengan baik.

Analisis peningkatan literasi sains mahasiswa dilakukan dengan menganalisis skor perolehan (gain skor). Data peningkatan literasi sains mahasiswa pada kelas coba terbatas. Perbandingan jumlah siswa yang dikelompokkan berdasarkan kategori gain skor ditampilkan pada tabel 7.

Tabel 7. Analisis Peningkatan Literasi Sains Mahasiswa

\begin{tabular}{|c|c|c|c|c|c|}
\hline No. & $\begin{array}{c}\text { Kode } \\
\text { Subjek }\end{array}$ & $\begin{array}{c}\text { Nilai } \\
\text { Pretest }\end{array}$ & $\begin{array}{c}\text { Nilai } \\
\text { Posttest }\end{array}$ & $\begin{array}{l}\text { Gain } \\
\text { Skor }\end{array}$ & $\begin{array}{l}\text { Kategori } \\
\text { Gain Skor }\end{array}$ \\
\hline 1. & 1 & 16,67 & 76,67 & 0,72 & Tinggi \\
\hline 2. & 2 & 30,00 & 93,33 & 0,90 & Tinggi \\
\hline 3. & 3 & 23,33 & 80,00 & 0,74 & Tinggi \\
\hline 4. & 4 & 26,67 & 80,00 & 0,73 & Tinggi \\
\hline 5. & 5 & 13,33 & 76,67 & 0,73 & Tinggi \\
\hline 6. & 6 & 23,33 & 96,67 & 0,96 & Tinggi \\
\hline 7. & 7 & 20,00 & 76,67 & 0,71 & Tinggi \\
\hline 8. & 8 & 30,00 & 86,67 & 0,81 & Tinggi \\
\hline 9. & 9 & 13,33 & 76,67 & 0,73 & Tinggi \\
\hline 10. & 10 & 20,00 & 80,00 & 0,75 & Tinggi \\
\hline \multicolumn{2}{|c|}{ Nilai Terendah } & 13,33 & 76,67 & 0,72 & - \\
\hline \multicolumn{2}{|c|}{ Nilai Tertinggi } & 26,67 & 96,67 & 0,96 & - \\
\hline \multicolumn{2}{|c|}{ Rata-rata } & 21,67 & 82,34 & 0,78 & - \\
\hline
\end{tabular}


Berdasarkan data yang disajikan pada tabel 7 diperoleh informasi bahwa pada tahap uji pretest semua mahasiswa masih memperoleh nilai dibawah standar capaian (50) walaupun kisi-kisi materi telah diberikan sebelumnya. Perolehan gain skor literasi sains semua mahasiswa menunjukkan peningkatan dengan keragaman nilai yang berbeda. Peningkatan literasi sains mahasiswa ditandai dengan semua subjek yang telah memiliki kategori gain skor tinggi yaitu lebih dari 0,7. Capaian nilai ratarata pada pretest yaitu 21,67 dan posttest yaitu 82,34 Gain skor yang diperoleh mahasiswa merepresentasikan capaian literasi sains mahasiswa yang mengalami peningkatan.

Gain skor tertinggi mahasiswa yaitu 0,96 dimana perolehan nilai pretest sebesar 23,33 dan perolehan nilai posttest 96,67 . Gain skor terendah mahasiswa yaitu 0,71 dimana perolehan nilai pretest sebesar 20,00 dan perolehan nilai posttest 76,67 . Hasil analisis dan pengamatan selama proses pembelajaran, literasi sains mahasiswa ratarata berkategori Functional Scientific Literacy. Hal ini bermakna bahwa mahasiswa mampu menjelaskan dan mendefinisikan konsep sains dengan benar dan secara ilmiah, tetapi memiliki keterbatasan pengetahuan tentang konsep tersebut sehingga penjelasan konsep sains kurang mendalam dan detail.

Keefektifan bahan ajar berorientasi environmental sustainability education yang terintegrasi kearifan lokal dengan tujuan untuk meningkatkan literasi sains mahasiswa dianalisis secara statistik menggunakan uji Mann-Whitney U dengan bantuan program SPSS 16. Hasil uji Mann-Whitney U menyajikan nilai Asymp. sig (2tailed) untuk nilai literasi sains mahasiswa $=0,0001$. Berdasarkan kriteria pengujian $\mathrm{H}_{0}$, nilai sig $<0,05$ menyatakan $\mathrm{H}_{0}$ ditolak dengan makna terdapat perbedaan yang signifikan dari rata-rata literasi sains mahasiswa pada pretest dan posttest. Berdasarkan pengujian hipotesis, dapat diperoleh kesimpulan bahwa bahan ajar berorientasi environmental sustainability education yang terintegrasi kearifan lokal efektif untuk meningkatkan literasi sains mahasiswa (dengan bentuk one group pretestpostest). Hasil penelitian dan pembahasan dipaparkan dengan panjang 60-70\% dari panjang badan artikel. Hasil analisis/penelitian adalah bagian inti dari artikel ilmiah. Hasil analisis/penelitian umumnya berisikan hasil analisis data, hasil pengujian hipotesis. Untuk memperjelas memaparkan hasil analisis/penelitian dilengkapi dengan bagan gambar, tabel dan/atau grafik.

\section{SIMPULAN}

Simpulan yang diperoleh dalam penelitian ini yaitu: Bahan ajar berorientasi environmental sustainability education berintegrasi kearifan lokal Mbojo untuk meningkatkan literasi sains mahasiswa kimia STKIP Bima dapat dikembangkan dengan karakteristik dikembangkan meliputi RPS, diktat kuliah dan instrumen penilaian literasi mahasiswa yang diimplementasikan melalui model pembelajaran project based learning pada materi Kimia Karbon dan Peranannya Terhadap Lingkungan, instrumen penilaian dikembangkan berformat benar salah beralasan dengan indikator literasi sains diadaptasi dari aspek competencies pada draft science 
framework PISA; bahan ajar berorientasi environmental sustainability education berintegrasi kearifan lokal Mbojo layak digunakan dengan kategori kelayakan sangat baik serta efektif digunakan untuk meningkatkan literasi sains mahasiswa dengan berdasarkan Mann-Whitney U yang menunjukkan nilai Asymp. sig (2-tailed) untuk nilai literasi sains mahasiswa $=0,0001$.

\section{DAFTAR PUSTAKA}

Dick, W., Carey, L., \& Carey, J. O. (2001). The Systematic Design of Instruction (5th ed.). Florida: Addison-Wesley Educational Publishers, Inc.

Hake, R. R. (1998). Interactive-Engagement vs Traditional Methods: A Six-ThousandStudent Survey of Mechanics Test Data for Introductory Physics Courses. American Journal of Physics, 66(1), 64-74. Retrieved from http://www.montana.edu/msse/Data_analysis/Hake_1998_Normalized_gai n.pdf

Jollands, M., \& Parthasarathy, R. (2013). Developing Engineering Students' Understanding of Sustainability Using Project Based Learning. Sustainability, 5(12), 5052-5066. Retrieved from https://www.researchgate.net/publication/272757438_Developing_Engineeri ng_Students'_Understanding_of_Sustainability_Using_Project_Based_Learnin $\mathrm{g}$

Masita. (2012). Pendidikan Karakter Berbasis Budaya Lokal pada Masyarakat Muslim. Jurnal Studi Masyarakat Islam, 15(2), 302-321. Retrieved from http:// ejournal.umm.ac.id/index.php/salam/article/viewFile/1668/1776

Micangeli, A., Naso, V., \& Matrisciano, A. (2014). Attitudes toward Sustainability and Green Economy Issues Related to Some Students Learning Their Characteristics: A Preliminary Study. Sustainability, 6(6), 3484-3503. Retrieved from

https://www.researchgate.net/publication/262679379_Attitudes_toward_Sus tainability_and_Green_Economy_Issues_Related_to_Some_Students_Learning _Their_Characteristics_A_Preliminary_Study

OECD. (2013). PISA 2015: Draft Science Framework. New York: OECD Printing Office.

OECD. (2014). PISA 2012 Results: What 15-Year-Olds Know and What They Can Do with What They Know. Paris: OECD Printing Office.

Perkasa, M., \& Aznam, N. (2016). Pengembangan SSP Kimia Berbasis Pendidikan Berkelanjutan untuk Meningkatkan Literasi Kimia dan Kesadaran terhadap Lingkungan. Jurnal Inovasi Pendidikan IPA, 2(1), 46-57. Retrieved from https://journal.uny.ac.id/index.php/jipi/article/viewFile/10269/8068

Redman, E. (2013). Advancing Educational Pedagogy for Sustainability: Developing and Implementing Programs to Transform Behaviors. International Journal of Environmental \& Science Education, 8(1), 1-34. Retrieved from https://eric.ed.gov/?id=EJ1008593

Shwartz, Y., Ben-Zvi, R., \& Hofstein, A. (2006). The Use of Scientific Literacy Taxonomy for Assessing The Development of Chemical Literacy Among High-School Students. Chemistry Education Research and Practice, 7(4), 203-225. 
Retrieved

from

https://pubs.rsc.org/en/content/articlelanding/2006/rp/b6rp90011a\#!divA bstract

Soobard, R., \& Rannikmae, M. (2011). Assessing Student's Level of Scientific Literacy Using Interdisciplinary Scenarios. Science Education International, 22(2), 133144. Retrieved from https:/ / eric.ed.gov/?id=EJ941672

UNESCO. (2002). Teaching and Learning for A Sustainable Future. Australia: Griffith University Publisher. 